\title{
Activist Pensioners, a Contradiction in Terms? Argentina's Jubilados
}

\author{
Lindsay DuBois \\ Department of Sociology and Social Anthropology \\ Dalhousie University
}

\begin{abstract}
Why does it seem unlikely that retirees should be political activists? What does that reaction say about our understandings of retirement and of activism? This article examines the experience of a group of older activists who, among other things, rally weekly in front of the National Congress in Buenos Aires, Argentina, and have done so for more than two decades. Regardless of advanced age and infirmity, these men and women, some in their eighties and nineties, refuse to be defined as passive by their roles as retirees and grandparents. After examining some of the tensions embodied in the idea of activist pensioners, this article proceeds to look at the pensioners' own understandings of where their activism comes from and what sustains it. Situating the pensioners' struggle in broader historical processes in Argentina illuminates their motives and strategies. The article thus also demonstrates that a historical approach provides a productive strategy for analysing elder social movements.
\end{abstract}

Key words: activism, ageism, Argentina, pensioners, social movements

\section{INTRODUCTION}

I found just the place for me...even though one doesn't accomplish great things. But we know what we want. We chose this...We aren't going to give in to power, staying home. It's good for us to be out in the street, doing something, awakening the recognition of folks. It's tied to the solidarity of others with you... It comes from my father and sharing a plate of food, and the neighbours...You are shouting for all that you've lived, all that. It's not disconnected from that. Others say that we don't accomplish anything.... It's about feeling good doing something. I'm proud to be President of a senior center where today, when it was 3 degrees below zero [Celsius], there were seven compañeros collecting signatures... And it's more than the cold numbers; that's 450 people [who signed] expressing solidarity. It's a commitment to solidarity, despite this trashy society we live in. Solidarity is the only thing that is going to save us... This morning we were cold, we were standing there... but it's comforting. We aren't too humble to recognize that we have done excellent work. It's still possible to rebuild solidarity. That's what we're hoping. We know we are fighting for human dignity.

- Hector Anzorena, retired waiter, activist pensioner

Hector Anzorena spoke these words in an interview in Buenos Aires in 2002 by way of explanation. He was trying to convey how and why he came to be so engaged in the work of the activist pensioners (called the jubilados) who are the focus of this article. The surprising thing is that he was not talking about a group of twenty-somethings standing on the street corner collecting signatures, but of older people, in their sixties, seventies and eighties. Hector, for example, was born in 1930, so he would have been 72 as he stood in the cold cajoling passers-by to acts of solidarity. 
Old age is supposed to be a life stage in which the passions of youth have been tempered by time and experience. Yet the women and men who are the subjects of this article continue to protest in the street, rallying weekly in front of the Argentine Congress in downtown Buenos Aires. This article considers the sense of the unexpected that the phrase "activist pensioners" evokes. Why does it have the air of the oxymoron? What does this tension between "activist" and "pensioner" say about the social position of the aged? Notwithstanding the particularities of the Argentine case, examining the tensions entailed in the idea of activist pensioners illuminates not only the situation of activists but also the place of pensioners and older people more generally in similar societies. The article goes on to consider the pensioners' own explanations of their activism and its sources. Throughout I take a historical approach, reading the personal experiences of particular activists in the context of larger political historical processes.

Judging by the literature, one might imagine that old age and activism are indeed contradictory states. General searches under these and related key terms turn up very little. ${ }^{1}$ Among the notable exceptions are Roger Sanjek's Gray Panthers (2009) which describes the history of the American activist organization by that name. The Gray Panthers and Sanjek's treatment of them provide an interesting point of comparison for the activists I discuss here. They are similarly contentious. They do not see theirs as a service organization, but rather enter political debate from a generational perspective, dealing with senior's issues - such as nursing homes, mandatory retirement, and health care - but by no means limiting themselves to them. ${ }^{2}$ Another well-known North American group is the Raging Grannies. The Grannies (organized into local gaggles) deploy their age and their gender in critical political street theatre, mainly as peace activists, but they do not take the issues of the elderly as their focus (Sawchuk 2013).

The scanty literature raises the question of whether older people are in fact rarely engaged in activism or, alternatively, whether their activism is underappreciated.
Both phenomena are probably at play. In most times and places activists are surely in the minority. Perhaps this is reason enough that studies of activist elders seem to be few and far between. Yet the jubilados felt themselves to be not just unusual amongst their peers, but also overlooked. They struggled with the problem of recognition (see Fraser 2000). Ideas about how older people should (and do) behave shape both what people are likely to do and how their behaviour is understood and reported. A thoughtful reflection by Meredith Minkler and Martha Holstein (2008) notes the political impact of the type of engagement deemed suitable for older people. Minkler and Holstein discuss dominant paradigms about the place of older people in the US, Canada and the UK, decrying the shift from "civil rights" to "civic engagement." Interestingly, they describe themselves as having entered the field of gerontology partly because they were drawn by people like Gray Panthers founder Maggie Kuhn.

As we see it... the vision of civic engagement that proponents put forward is essentially a de-politicized strategy to encourage, facilitate, and normalize community participation in old age. It does not call for analysis, critique, or change in the social and political assumptions and consequent political agendas that now prevail in much of the industrialized west, which have the potential to harm the less advantaged members of this and subsequent cohorts. What then is the resemblance to the heady - and highly politicized early days of the Gray Panthers, let alone the Townsend Movement, Civil Rights and the Women's Movement

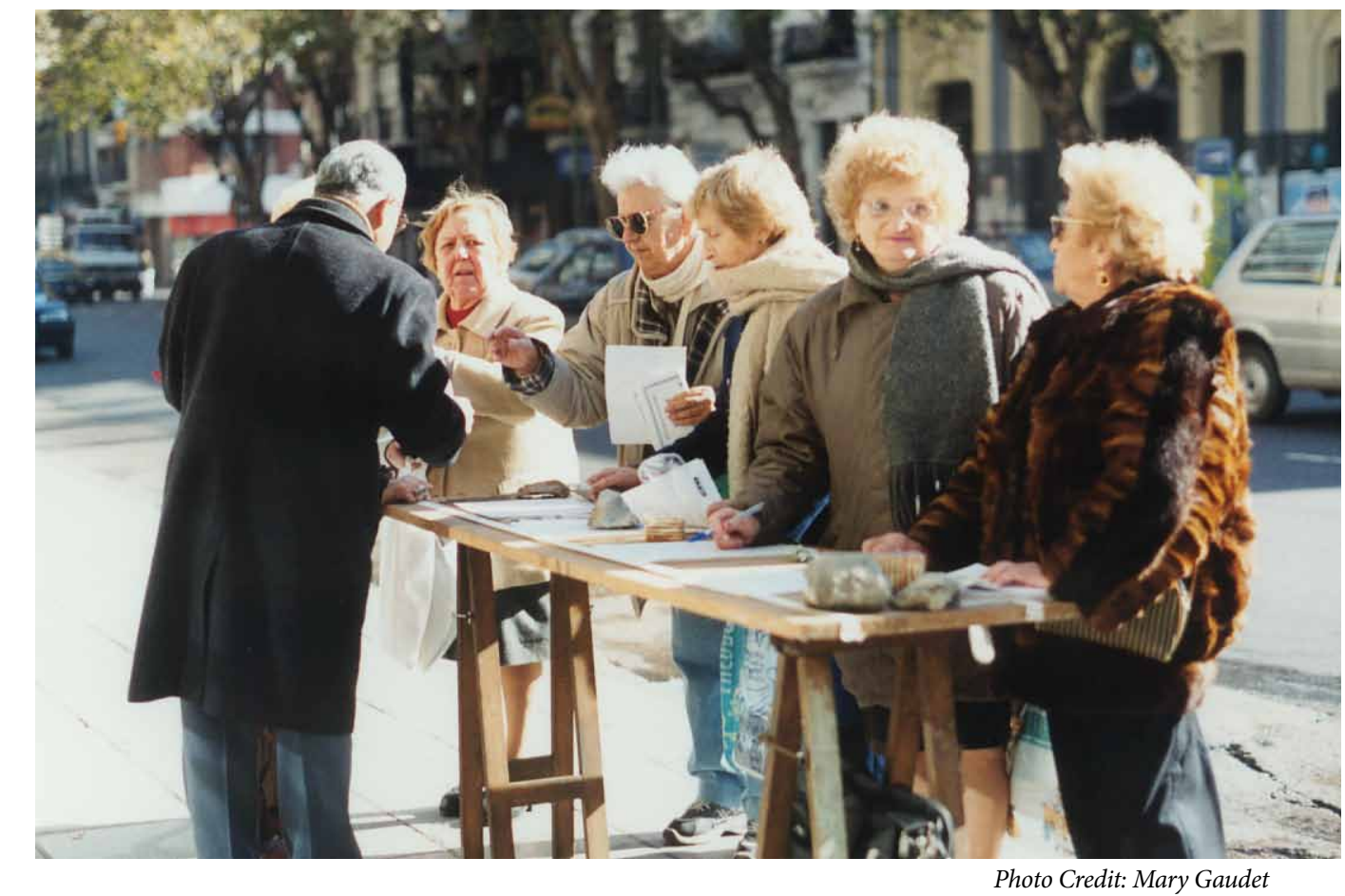


to which it is sometimes compared? (Minkler and Hosltein 2008:197)

In other words, the narrowly conceived civic engagement model fits neatly with the agendas of nation-states seeking to reduce their social welfare roles, placing responsibility on individuals to pick up the slack. The emphasis is on activity, but not activism in its overtly political sense. The political projects of groups like the Gray Panthers and the Jubilados are not what those touting "active aging" have in mind.

\section{The Research}

The research discussed here was conducted in Buenos Aires primarily between September 2001 and June 2002, with supplementary bouts of fieldwork in 2003 and 2006, (and occasional subsequent conversations). The timing is significant. The main fieldwork began at the close of a decade of increasing economic hardship in Argentina. The economic crash of 2001 led to a dramatic upsurge in popular mobilization, especially in Buenos Aires, where pensioners joined crowds of people banging on pots in protest. This context often strongly shaped discussions, interactions and how the pensioners understood their struggle.

Conceived as an oral history project, the research centered on life history interviews and a history workshop conducted in one the movement's allied senior centers. It also involved participation in the weekly pensioner's protest marches, attendance at talks, and study of the various official statements made by the pensioners' organization -press releases, flyers, occasional newspapers, and (later) blogs. The life history interviews were conducted with thirty-one people who participated actively in the jubilados' movement or its allied center. ${ }^{3}$ These interviews were usually conducted in one or two sessions. They ranged from twenty minutes on a street corner, to seven hours over three meetings. Interviews took place in locations preferred by the pensioners, often cafes, but also in people's apartments, the offices of the retirees' organization with which I worked, or a senior's center.

My central concern in these interviews was the question of where activism comes from. Yet this question was framed as broadly as possible and placed in the context of life history. For example, interviews usually began with the question, "when and where were you born?" Many people answered this question by describing their parents, often noting where their parents came from if they were first generation Argentines (as many were).

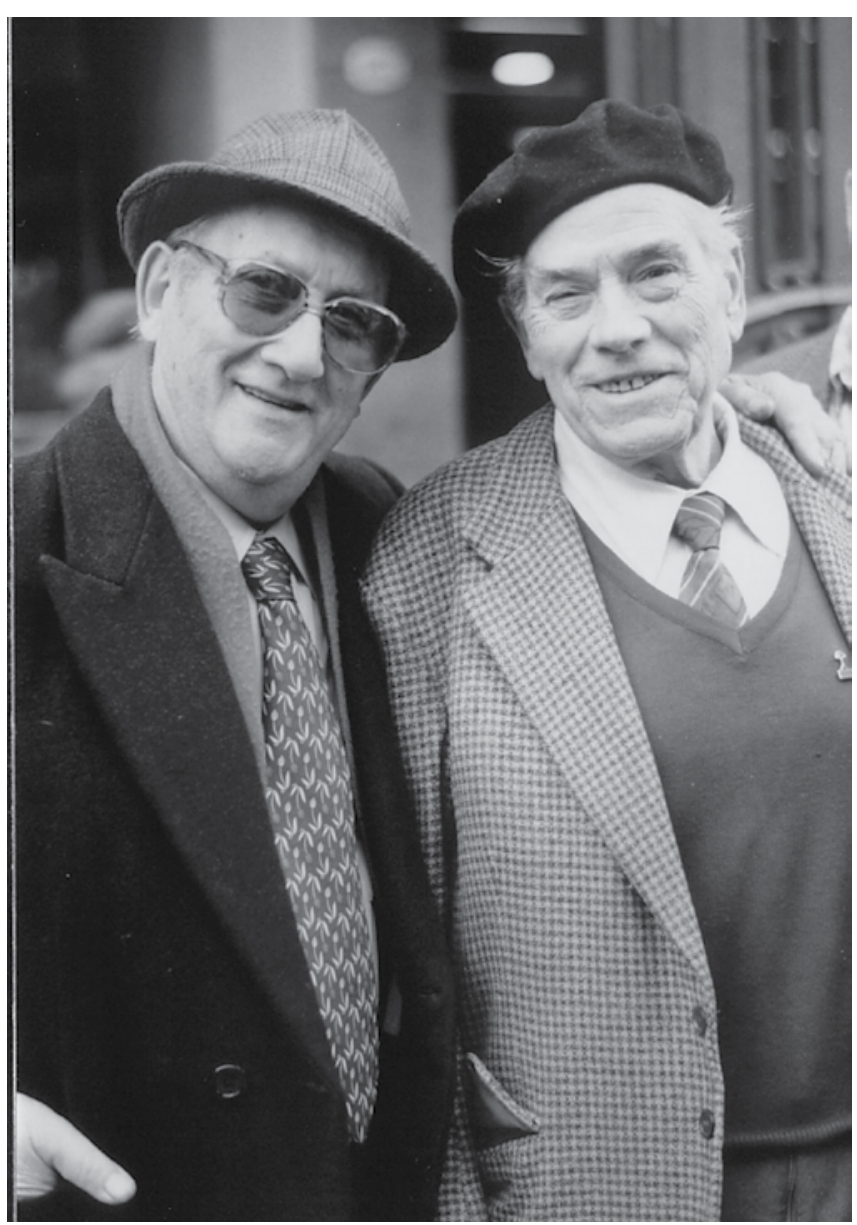

Photo Credit: Mary Gaudet

Descriptions of childhood often followed. I was interested in how different jubilados framed their lives, noting the ways in which these accounts were structured. I read these differences as saying something about people's public personas, or perhaps the personas they wanted to present to me in particular. Women were more likely than men, for example, to discuss their family obligations, and to structure their accounts around domestic events like marriage and the birth of children. By contrast, for some men, I had to pointedly ask if they had ever been married before I learned anything about their domestic lives. Some told their life stories through an account of the different labour unions they had belonged to. Luciano, ${ }^{4}$ for one, portrayed himself as a scrapper by focusing on the different labour conflicts of which he had been a part, with particular emphasis on moments when physical violence was involved, either within unions or between workers and police or military. 
Whereas the life histories were narrated to and for the interviewer, the history workshop saw jubilados speaking to each other; different kinds of conversations resulted. When I began this research, I asked people at the main group organizing the seniors, the Coordinating Committee of Argentine Retirees and Pensioners (the Mesa Coordinadora de Jubilados y Pensionados de la República Argentina, known as the Mesa), if they knew of a senior's center which might host a history workshop. Someone pointed me in Hector Anzorena's direction. He invited me to meet people at the Abasto-Once Senior's Center (Centro de Jubilados y Pensionados Abasto-Once, known simply as Abasto-Once, after the neighbourhoods near which it is located) where he was then President. ${ }^{5}$ As the quote from Hector at the beginning of this article attests, members of this center tried to engage people in political discussion about the pensioners' plight. Over three months, a small group of between three and seven jubilados met late Friday afternoons to drink tea and mate cocido (an Argentine beverage, prepared like tea), nibble on cookies, and discuss the past, present and future. Some workshop meetings were discussion based; some focused on a life stage such as childhood, others considered the broad historical sweep of the the history through which the jubilados had lived, still others addressed the history of the jubilados' movement. The workshop attempted to make a video about the jubilados' struggle. Although the video never happened for financial and logistical reasons, the planning process focused the group's discussion on questions of how the political struggle should be portrayed and to what ends.

Before proceeding to describe the jubilados, a note on terminology is in order. I call the elder activists who are the focus of this work "jubilados" using the Spanish term for retiree. This is the term most of the people I spoke to used to describe themselves. Coming from júbilo meaning joy, the word has a positive connotation noted with a heavy dose of irony by many jubilados. The Mesa, as noted above, is formally called the Mesa Coordinadora de Jubilados y Pensionados de la República Argentina, to cover both the class of people that we think of as "pensioners" in English (that is people who have retirement benefits resulting from their work) and those receiving other kinds of state payments. For example, war veterans and the disabled are two groups of Argentines receiving pensions. Several individuals I met in the course of this research pointed out that they were not properly jubilados, because they had not retired from a job that paid pension benefits. Nonetheless, the common term for the group was the Jubilados which was also the title of their semi-regular newspaper. Thus I use this term in Spanish to refer to the activist pensioners in this article using upper case to refer to the group and lower case to refer to members. Note also that "jubilada" is the feminine form.

\section{THE JUbILAdOS AND THEIR HISTORICAL CONTEXT}

The elders who are our focus are by no means typical pensioners. For more than 1100 consecutive Wednesdays they have protested at 3 p.m. in front of the Argentine National Congress in downtown Buenos Aires. These weekly rallies began in 1990, moving to their current location in 1992 and continuing to the time of writing. At the rallies, a series of speakers, mostly from the Mesa but including visitors, address the crowd from the back of a small truck. They speak to the issues of central concern to the elderly, especially pensions and health care, but also take up many other questions about which they have strong views, including both national and international political debates. Over the last decade the rallies have tended to be relatively small, involving as few as forty jubilados and supporters. At their peak in the 1990s, however, they sometimes included thousands. Photographs from that period show aged protesters confronting police in riot gear.

Although a social movements approach to the jubilados might focus on their common identity and their common plight in the present and leave it at that, it is instructive to approach the group historically. As the jubilados themselves often argue (and as discussed below), their struggle needs to be understood as a consequence of historical processes. It is very much shaped by the history of Argentina in the 20th century. In a chapter on how we should think about individuals, Philip Abrams (1982) argues that the concept of generation for historical sociology differs from that of common sense. Rather than depending on biological reproduction, generation has to do with the historical conditions, especially socialstructural ones, that characterize everyday life. ${ }^{6}$ Thus, just as in certain periods with little social change a generation could last one hundred years or more, in others, where social change is more rapid, generations describe much shorter intervals. The jubilados constitute a generation in this sense, marked by crucial socio-historical processes and arrangements in Argentina. Most of those I spoke with were working-class people born before 1930, so their historical experience positions them as observers of the rather dizzying Argentine political scene stretching from childhoods before the advent of Peronism, through the Peronist decade, dictatorship, democracy, industrialization and deindustrialization, as well as boom and bust several times over. As one jubilada in the history workshop put it, "It's a very rich and contradictory history." Jubilados 
note that these political and economic changes have been accompanied by social and cultural ones.

The generation under discussion is the first to have entered the workforce with a reasonable expectation of receiving a pension. Before Juan Domingo Perón came to power in 1946 a small number of workers received pensions, but it was Peronism, harnessing Argentina's post-war economic boom, that built its modern welfare state. ${ }^{7}$ Perón's government was also the architect of the peculiar Argentine healthcare system, described further below. Perón was removed from office in a 1955 coup. Much of the rest of the century, one might argue, saw leaders - both military and elected - trying to undo the kind of state which Perón had made. This unmaking process was most violent in the last dictatorship (1976-1982), but it was also very much a project of the government of Carlos Menem (1989-1999) (Grugel and Riggirozzi 2007). For example, President Menem earned special recognition from the World Bank and International Monetary Fund for the effectiveness of structural adjustment policies he was implementing (also widely described as neoliberal policies). Menem oversaw the widespread privatization of state enterprises and institutions, cut back state spending, and further opened the country to foreign investment. It was Menem who tried to privatize all state pensions. Meeting with considerable resistance, this plan was altered to an optional one designed to encourage people to move out of the state pension system.

The dire situation of the pensioners became a public issue in the early 1990s, illustrating the human cost of the economic model. The press reported a wave of suicides, apparently a consequence of the despair seniors felt at the prospect of trying to survive on meagre pensions which had fallen far behind inflation. At that time in the early 1990s, pensions covered about $12 \%$ of the cost of living (Lloyd-Sherlock 1997:65). Pensioners could not feed themselves, much less pay for rent or medication. If you mention the jubilados to people old enough to remember the early 1990s, the image that comes to mind is an incident which dramatized the Jubilados' struggle. Ailing pensioner Norma Pla confronted the architect of the neoliberal economic model, Minister of the Economy Domingo Cavallo. The cameras were rolling when she brought Cavallo to tears by berating him about the plight of the country's seniors (Zommer 1996). ${ }^{8}$

In addition to the level and timeliness of pension payments, healthcare is the jubilados' other key issue. In order to understand the particular institutional importance of healthcare to the pensioners, the peculiar structure of the Argentine healthcare system - a material legacy of Peronism - warrants some explanation. One of the ways
Perón expanded working class rights, on one hand, and consolidated working class support and control on the other, was through the obras sociales [literally "social works", actually benefits and services]. A broad range of social services and benefits, including health care, were distributed through the massive labour unions via obras sociales. Peronist Argentina used unions to organize Argentine society by including virtually all workers in unions organized by profession (for example, as a waiter Hector was unionized) (Rock 1987: 263). The system, though, was designed to incorporate people via their work, including dependent children, but leaving retirees uncovered. PAMI $^{9}$ was created to fill the gap, providing health care and other benefits to pensioners and other seniors. PAMI covers millions of Argentines, primarily jubilados, and is the largest health plan in Latin America. Like the pension funds, PAMI's enormous budget which the national government administers presents an attractive way to adjust public accounts in economic hard times.

PAMI then, although ostensibly available to all pensioners, has not always provided the health care it promises. Particularly during the 1990s and the early 2000s, there were periods when PAMI was in arrears in its payments to doctors, hospitals or pharmacies. As a consequence, health services to seniors were often dramatically reduced or curtailed altogether, sometime for months at a time. Likewise, medicines were sometimes available free of charge, while at other times unavailable. A third problem which seniors experience with PAMI is the elaborate bureaucratic complexity which, to an outsider, almost appears designed to discourage potential users. In order to renew a prescription, for example, a senior often had to go to her general practitioner, to the PAMI offices and then to the pharmacy, sometimes waiting for hours at one or more of these locations. It was quite common for people to go to hospital clinics at six in the morning in order to be in the queue when staff arrived at 8:30 in order to get an appointment to see a doctor later in the day. One then had to line up again to actually see the doctor. People sometimes joked that you needed to be retired to have the time necessary to receive PAMI health services. The overall experience was of a health care system that was uneven, unreliable and demanding.

Considerable public support led to some material progress for pensioners by 2001, when I began to work with them. However, this was a moment in which the Argentine economy was moving towards its spectacular crash. The events of December 2001 included the largest national default in history (up to that time). This, in turn, led to an upsurge in popular mobilization. Pensioners joined large protests of people banging pots, and attacking bank offices 
and automatic tellers. There were also widely publicized lootings in December, and massive mobilizations of the unemployed which often blocked major highways (Vilas 2006). Five interim presidents and two years later, Nestor Kirchner, a Peronist, was elected in 2003. He and Cristina Fernández de Kirchner who succeeded him (she was his political partner and wife) reoriented social and economic policy. Since the change in economic models, the state has considerably expanded its welfare functions, extending pensions to large segments of the population. ANSES, the newly nationalized pension agency, extended pension coverage to an additional 2.3 million Argentines bringing the total number of pensioners to 5.6 million in 2010, expanding coverage from $57 \%$ of seniors in 2003 to $88 \%$ by 2010 (Cufré 2010; Bossio \& Boudo 2010). The government has also indexed pensions to inflation. This is another boon to jubilados who have often found gains won through struggle evaporate again as the peso lost value. Anecdotal evidence suggests that health care has also improved, although this is harder to measure.

\section{The Jubilados Today}

Although the jubilados say they are pleased with these gains, they also eschew asistencialismo, (welfare-type social assistance) which they believe undermines their rights as former workers. Instead, the Mesa has insisted that the original terms and conditions of their pension plans be honoured. The organization continues to focus on increasing the pay level of pensions, and specifically on a longstanding demand to set pension scales at $82 \%$ of current salaries of the same job and rank, as specified by law. The jubilados contend that they have historically and unfairly been "a variable in structural adjustment" equations [una variable del ajuste] (de la Sota 2008) since both their pension plan and their state-administered health care plan are large funds that the state can dip into for other purposes (and scholars agree, see Dantz 2012).

A 2008 letter to the editor of La Nación, the most elite of the national newspapers, captures the sense of grievance:

After all this time I have realized that the pensioners' problems are only of interest to pensioners, and often not even to them, because they are already defeated, full of suffering; it seems as if they just wait for the only thing that is certain in this life: moving on to eternity. Today, as always, they are mistreated, even by their own families. So why should we imagine that journalists would pay attention to us? That the government should help us?

We have always been the variable in [structural] adjustment and we never realized that we were pensioners; we always wanted to avoid talking about it. Why talk about my pension if I'm still young? And the years pass and those who make it have to suffer the consequences of being "old". Who will pay attention to us? If we are not productive [working], we are only an expense in their budget line.

To understand all this you only have to look at our daily lives. Who gives a seat to an older person (now very few)? Have you seen how they are treated in the lines at the bank? Have you seen how they are treated in hospitals? The only moment in which we are more or less important is at election time, where the politicians tear their clothing to fight for our rights.

It is very difficult for a country to have a future if it doesn't respect its elders. Is that why we are in the state we're in? God willing, today's young people at some point will really think about the future and not forget that then they too will be older people. [de la Sota 2008]

This writer calls out not just the government and the press, but also Argentines in general. For him, the policy problems are an effect of the larger invisibility of the aged. Like this letter writer, the Jubilados see ageism as one of the underlying causes of their economic plight.

The Jubilados are socially positioned so as to make their activism appear unlikely in at least three ways. First, they are not workers. Second, and related to the first, they are thought to be passive. Third, ageism means they are thought to be different from, even less than, those who are not old. The first of these, that pensioners are not workers, is especially important in the Argentine context. As the explanation of obras sociales above suggests, one effect of Peronism was to make work a powerful organizing principle for the society as a whole (Karush \& Chamosa 2010). This is partly because Peronism mobilized labor, making labor unions key players on the political scene. In addition, the obras sociales further enlarged the role of unions in the everyday lives of working-class people. In Argentina, retirees are defined as part of the "passive class" (la clase pasiva), and are explicitly contrasted to those currently working who are described as "en actividad." In other words, work is closely tied to activity.

In a complex and nuanced analysis of the changing connotations of "dependency" as a key word in political culture in United States, Nancy Fraser and Linda Gordon (1994) show how the idea of dependency shifts to become more negative, and to be increasingly read in the "moral/ psychological register" (1994:332) as an individual failing. They connect this process to the stigmatization of welfare recipients, and especially the emblematic recipient of social assistance, the welfare mom. Likewise in Argentina, receiving social assistance marks one as needy and dependant, which is understood to be negative. ${ }^{10}$ Within this larger constellation of ideas, children and old people are quite often seen as "the deserving poor" (Will 1993); 
that is, as legitimately needy. That legitimacy is tied to an understanding that children and the elderly should be protected and cannot be expected to fend for themselves. Fraser and Gordon note that the problem with this sort of reasoning is not so much that some groups are seen as dependent, but rather, that independence is assumed to be an unmitigated good, a virtue. Seeing senior citizens as the deserving poor often goes hand in hand with seeing them as less capable, as recipients rather than agents.

It is this view of senior poverty that Norma Pla's exchange with Minister Cavallo (described above) evoked. It is a view of neediness that presumes passivity. ${ }^{11}$ Given that Norma Pla was something of a folk hero, I was a bit surprised by the degree to which leaders of the Jubilados movement were uncomfortable in talking about Norma Pla and hesitant to celebrate her. On reflection, it seems their reaction was partly a response to the way her message played up the pathos of pensioner's situations, pulling on the heart strings, rather than calling for the recognition of rights and entitlements.

It is worth noting that children and the aged have been the focus of the dramatic poverty reduction policies advanced by the Kirchners in Argentina since the crash. The state's strategy has effectively reduced extreme poverty in the country. Yet the jubilados are not satisfied. The increased spending has focused on incorporating many more people and raising minimum pension payments in the context of inflation. This strategy has the effect of converting the pension system into a form of social assistance. When jubilados criticize asistencialismo, they are making precisely this distinction. The activist jubilados see their pensions as deferred wages. They do not seek hand-outs; they want their due as workers. ${ }^{12}$ Ageism aligns with these notions of neediness and passivity. Older people are supposed to lack the energy and imagination for activism..$^{13}$ They are also thought to be rigid and isolated, except perhaps for family.

\section{Organizing Argentine pensioners}

As the jubilados I worked with often noted, only a tiny proportion of pensioners participated in their movement, raising questions about the degree to which older Argentines are organized and in what forms ${ }^{14}$. A helpful study (Fassio \& Golpe 1999) surveyed formal seniors' organizations in Buenos Aires in 1998. The study underlines the diverse ways in which older people were in fact creating spaces of solidarity and social interaction, notwithstanding "the dense proliferation of contemporary ageism" (1999:73) and alienation which the authors observed in Argentine society. For Fassio and Golpe, the variety of elders' organizations offer up spaces, "with identity, with history and the possibility of social relations" (1999:73). Furthermore such spaces "not only optimize the objective living conditions of the aged, but invigorate their self-organizing capacity in the fight for rights for one of the most vulnerable social groups" (1999:73-4).

Of particular interest is their analysis of the type of organizations in which older people are involved (see table 1).

\begin{tabular}{|l|l|l|}
\hline TYPE OF GROUP & NUMBER & $\%$ \\
\hline Recreational & 723 & 84.6 \\
\hline Religious & 39 & 4.6 \\
\hline Political & 36 & 4.2 \\
\hline Work related & 32 & 3.8 \\
\hline Representative Associations & 8 & 0.9 \\
\hline Programs & 7 & 0.8 \\
\hline Ethnic groups & 4 & 0.5 \\
\hline Rights groups & 3 & 0.4 \\
\hline Mutual Benefit Society & 1 & 0.1 \\
\hline Unclear & 1 & 0.1 \\
\hline TOTAL & $\mathbf{8 5 4}$ & $\mathbf{1 0 0 . 0}$ \\
\hline
\end{tabular}

Table 1: Distribution of Older People's Organizations in the city of Buenos Aires by number and percentage (Fassio \& Golpe 1999: 81).

Of 854 organizations in the city of Buenos Aires ${ }^{15}$ which were registered with either the city or the national governments, the vast majority $(84.6 \%$, or 723$)$ were recreational. Most of the others were evenly divided between religious $(4.6 \%$ or 39$)$, political $(4.2 \%$ or 36$)$ and work related $(3.8 \% \text { or } 32)^{16}$ (Fassio \& Golpe 1999:81). Only eight organizations fall under the category "representative associations." This would include the Mesa as one of the groups which organize and represent local groups such as seniors' centers.

The Mesa was founded in 1968, partly around the health care problem outlined above: the system was organized around labour unions such that workers and their families lost their coverage upon retirement of the unionized worker. The Wednesday rallies organized by the Mesa have been the public face of the pensioners' movement since the 1990s. Their other activities include: lobbying, 


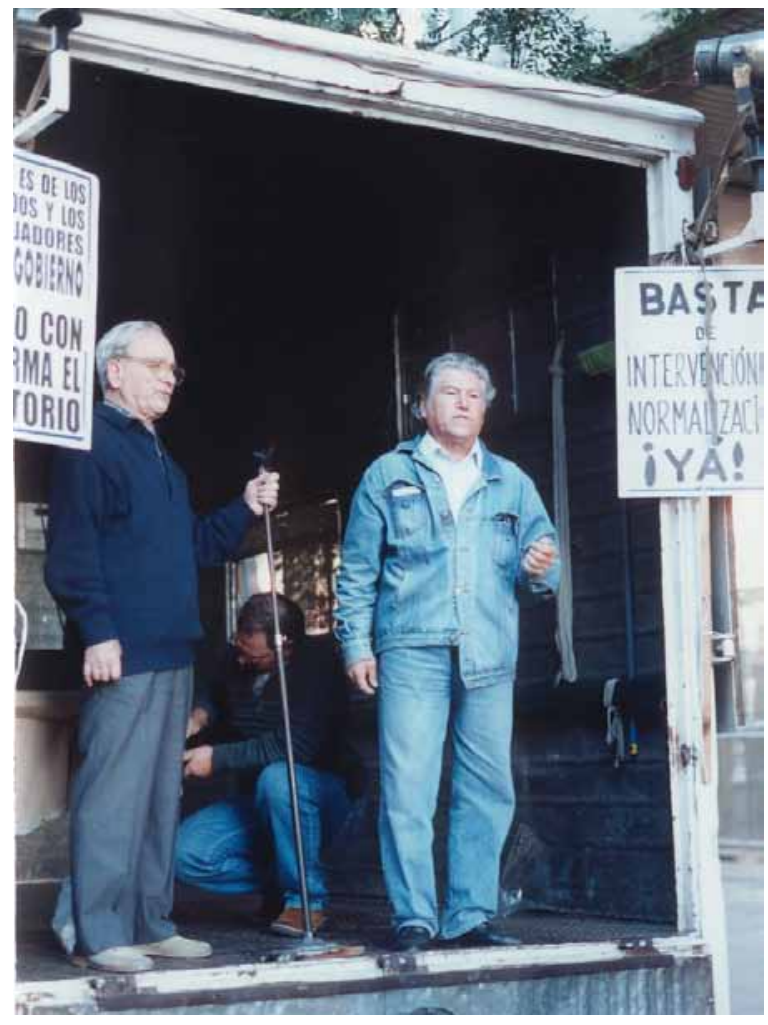

Photo Credit: Mary Gaudet

producing flyers, organizing talks and conferences, and publishing an occasional newspaper (now replaced by a blog), participating in other demonstrations, and working in coalitions. The visibility of the pensioners and their issues has also varied widely across the years, at times making the front pages of the national press, as in the Norma Pla incident, at others disappearing from public view.

Some jubilados argue that media attention was not the main reason for their popularity; there were more concrete and specific reasons for the popular support in the days of the massive mobilizations. For example Luís Cortadi, a retired railwayman and long one of the central figures in the movement, insisted that there had been more specific and practical actions which explained why people started to show up for the weekly marches. The jubilados' organization had helped people sue pension funds, lobbied for exemption of property taxes for seniors, and convinced the city to let seniors ride the subways for free, among other things. Furthermore, when the government made a move to privatize the pensions in 1994, the Mesa mobilized 40,000 protesters and collected one million signatures in opposition. ${ }^{17}$

At present, amidst a political climate which accepts the legitimacy of pensioners' claims to a decent living, they seek a minimum equal to the national minimum wage as well as pensions payments which reflect current wage levels for similar jobs as already discussed. They also seek control of PAMI, for which they argue pensioners pay. The pensioners' situation, therefore, goes directly to the question of the state and its responsibilities. Furthermore, as Roger Sanjek notes for the American Gray Panthers, their situation makes the state the obvious target for their activism. With respect to the United States, Sanjek argues, "as 'the key determinants of the standard of living enjoyed or endured by the aged' became 'national and economic policies,' older Americans organized to confront the state at their point of exclusion - chronological age from the working class and its struggles" (quoting Estes in Sanjek 2009:4). Similarly, the jubilados might be seen as a counter-hegemonic group; their struggle is in many ways a direct response to the conditions of their exclusion and subordination. Likewise, their overall strategy is an effect of their situation. On one hand, their efforts are directed at making themselves seen and heard through their public demonstrations. On the other, they attempt to shape government policy and legislation. Ideally, in their view, congress-people might stop in at their demonstrations on the way to the legislature. Although this very rarely happens these days, they hope at least to be noticed as politicians enter the Congress. Representatives of the Jubilados do also lobby congress-people on their issues. In 2010 opposition groups took up some of the Jubilados' demands, incorporating them into proposed new legislation that would have dramatically increased pension payments for many. This legislation did not pass.

\section{Why ACTIVISM?}

In light of the way elder activism is thought to be unlikely and appears to be quite uncommon, one wonders how these elders came to be participating in the jubilados movement in their various forms and to their different degrees. In this section of the article, I turn more fully to jubilados' explanations of why and how they do the unexpected. These explanations point to the importance of generation in the Abrams sense (as discussed above).

One striking characteristic of the activist pensioners was that the vast majority had some kind of history in "the old left" - as communists, socialists and anarchists (Tortti 2009). Their political experience was quite diverse. Some were current members of the Communist Party or one of the various socialist parties, others had broken with their parties, still others spoke of an identification or sympathy with the old left. This identification was often described as emerging from concrete experiences in some of the institutions the parties sponsored, especially before the advent of Peronism. One must recall that Argentina is a 
country in which the intervention of Peronism from 1943 challenged, to a degree incorporated, and eventually all but eliminated leftist traditions from working class life. Most working-class people in the interim have been Peronist. The non-Peronism of these jubilados is therefore striking, in part attributable to their age since they mostly came of age before Peronism, but by no means reducible to it.
Occasionally we went for coffee afterwards; Burger King had a cheap coffee and pastry combo preferred by Ramón and his older anarchist-Spaniard friend José. As in all the interviews I conducted, I asked Ramón about his political life and how he came to be protesting at the Congress. He told me he had been a socialist in his youth, in large part because of the library the socialists ran in his neighborhood, but did not really consider himself very involved in the party. As he put it: "I voted. I went [to the socialists] because they had a nice library; I spent hours reading in the library. I wasn't an activist. I wasn't a hero, not an activist, not a fighter, none of that. I always liked the books." Ramón also described himself as a person with a penchant for lost causes.

Like Ramón, many of the jubilados point to what I have come to think of as an urban left-working-class milieu as a source of their progressive values. Most participated in, or were influenced by socialist, communist and anarchist messages which characterized urban working-class communities in Argentina before the advent of Peronism in 1943. For Ramón this was the socialists and their library. For Hector, with whose words I began this article, the values of justice, solidarity and integrity were learned Photo Credit: Mary Gaudet

This connection to the "old left," though extremely varied, is suggestive. In trying to unpack the link between the activist jubilados and the old left, I have identified several threads. One is institutional: the Peronist and Radical parties have historically run a plethora of senior's centers which draw members of those parties. These mainstream party-affiliated centers, although mostly recreational, do sometimes mobilize people on behalf of their parties, but not against the state. It is likely that many of the groups characterized as "recreational" by Fassio and Golpe (1999) would be of this type. The other threads connecting the jubilados to their left history was articulated clearly by the jubilados in the interviews and the history workshop. One has to do with values and commitments. Another is tied to the longer arc of their life stories.

\section{VALUES}

Ramón Sanchez, 72 when I interviewed him, was retired from skilled-labour in a refrigerator factory, although he still did a little work on the side. Ramón is not a leader of the Jubilados movement. Nevertheless I met him week after week at the demonstrations in front of the Congress. from his anarchist baker father and articulated in the anarchist newspapers read at home. Ramón's friend José was a veteran of the Spanish Civil War and continued to be fiercely anarchist. Others identified with the Communist Party. Regardless of their particular origins, most jubilados see their engagement as a consequence of values like solidarity, justice, and nationalism. This may be counterintuitive (or even sound self-congratulatory) for a movement expressly built around specific concrete demands like improved pensions and healthcare, but most of the jubilados noted that there were millions of Argentine pensioners who might have been involved but were not. They explained the differences between themselves and the many others whose interests they represent in terms of these values.

In addition to these more abstract principles, the jubilados also saw their struggle to defend the rights of the elderly as calling Argentine society to task. They worried that elderly people were pushed aside and not taken into account. From my vantage point in middle age, I was often struck by the way these evidently feisty people in their 70s and 80s lamented the poor treatment of people who were truly old and vulnerable - not placing themselves in that category. 


\section{TRAJECTORIES}

Most jubilados asserted that values and commitments alone did not explain why people participated. The values which underwrote participation were accompanied for many by concrete experiences over the span of their long lives. These questions were addressed directly by participants in the history workshop.

As already mentioned, the group dedicated quite a lot of attention to the larger political project of the Jubilados. The workshop participants had planned to make a video based on their deliberations; for a variety of reasons that video never came to fruition, nonetheless the discussion and debates about how and why it should be made were illuminating. With respect to this question of their trajectories, participants in the workshop commented, "we have come from a history of struggle. We were born fighters." They saw themselves as paving the way for the political mobilizations happening all around us as we met in March 2002; they called themselves "pioneers of resistance" and compared themselves to the international human rights heroines the Madres de Plaza de Mayo. ${ }^{18}$

For example, when I pressed Ramón about why he went to weekly protests in front of the Congress, he replied: “Truthfully, I don't know... But there is something which people carry until they die. I know I have to be present now because I have to keep fighting. Behind every jubilado, you see something. Behind each jubilado there is a militancy." He went on to elaborate: "behind every jubilado there is one who wrote, one who was a shop steward, another [who was] a different sort of union man.
We have life stor[ies]." Ramón continued by pointing out that his participation and experience is modest compared to some, speaking with respect bordering on awe of fellow jubilados who took big risks, were detained during military regimes, and so on.

Certainly the evidence supports Ramón's argument. Sanjek notes a strikingly similar process among the Gray Panthers. "[I]t was not involvement with senior citizen issues that brought most people to the Gray Panthers. It was rather lifetimes of engagement with labor struggles, civil and human rights, economic justice, health care and peace - from the 1930s onward for the older Panthers and during the 1960s and early 1970s for younger members" (2009:5).

A number of the jubilados had long histories in political parties and in organized labour, but as Ramón might note, these are often on the losing side of national and local struggles. The left parties have only ever had a small number of elected seats. Union politics in Argentina are tied quite directly to party politics, meaning that the groups within unions to which most jubilados involved in labour belonged were also usually in the minority. The life experience engaged within unions and labour struggles more generally were formative for many of the men and some of the women with whom I spoke. This connection is unsurprising given the important place of union politics historically in Argentina. One of the effects of this, though, was that many felt doubly adrift upon retirement. Not only did they leave their working lives behind, but the unions to which they had often devoted much of their political energies, were likewise closed to them. Nostalgia for past days fighting the good fight was apparent in many of the life history interviews. These jubilados described joining the activist pensioners as a solution to this problem. The Jubilados' movement offered an opportunity to put their skills and experience to work in a meaningful way. For a few, the connections were more direct. The late Antonio Fortes, a former shoe-maker born in 1914, and President of the Mesa when I interviewed him, built his life within the Argentine Communist Party, meeting his wife there, and joining the Jubilados at the Party's request.

Although labour union participation was a common precursor to involvement with the jubilados, there were others. Ramón, for example, was quite clear that his participation in the jubilados' protests represented a new, heightened degree of 
political involvement. He had never been involved in union activity. Women in general were less likely to have held important roles in unions, both because they were less likely to have engaged in unionized work, and because of the sexism of most of the unions at the time. Women jubiladas were also more likely to bear the brunt of family reproductive labour, obligations which held their energies and attentions in their middle years. Although many of the women I spoke with still had domestic obligations looking after grandchildren part time, the lessening of these responsibilities permitted their participation with the Jubilados. Interestingly, quite a few of the women were widows, perhaps with greater autonomy than those with husbands to care for. Dora García, for one, dated her entry into the jubilados' movement from the marriage of her children. Notwithstanding a period of heightened domestic responsibilities, most women could point to an earlier moment in their lives where they had been involved in political activities. The differing trajectories also help to explain why men occupied virtually all of the leadership roles within the Mesa, even though women outnumber men in the elderly population.

Struggling to explain how people came to the Jubilados, Ramón told me: "People are like wine. If the wine is good, with the years it will get better. If it's bad, it's poison." He thus underlined the continuities, especially of character, which he felt explained why some people chose to take up the quixotic task which the jubilados embraced. Elegantly aged wine is certainly a nice metaphor, but it is interesting that Ramón's explanation also takes up the question of the less-than-virtuous.

\section{BEING OLD AND AN ACTIVIST}

Finally, it is important to acknowledge some of the ways the jubilados' age shapes their social movement. Spending time with the jubilados one can forget their chronological age partly because they resist being defined by it. Yet there are moments when it comes to the fore. Yolanda, a workshop participant, described a debate that arose at one of the community assemblies [asambleas barriales] that sprung up in the wake of the 2001 economic crash. In a discussion about the video we hoped to make about the jubilados, Yolanda told the other workshop participants:

Last Monday I was at the community assembly and the inter-community assembly was there. And I stayed, and people were speaking and the problem of the pensioners came up, and I was allowed to speak. Two or three people, a man who was quite old, said to me, "You are focussing [too much on] this topic..." (He was very parochial, this guy) "Because the Jubilados, you are just another group that protests, you need to ask [more broadly] for justice." And I said "Look, we are one sector, but we are four million and some, who are reclaiming PAMI, which is pretty representative." There are people who don't give the issue priority... But we have a shorter life expectancy... With luck I will be able to live to eighty. I have nine years left. How am I not going to worry about this problem? [Mutters of agreement from all.] We don't have thirty years. There are still people who see us Jubilados as a little thing... I don't disagree with having [the video] present people's histories, and with giving it a more political tone, but we also have to bring ourselves closer to these sectors, that don't do anything, but who for ten years have been collecting $\$ 220$ or $\$ 150$ pesos [in monthly pension payments].

Yolanda's commentary brought together several themes. She raised the relationship of the pensioners' issues to a larger set of political demands. She asked the other workshop participants to think strategically about how much to frame the Jubilados' agenda in the language of the old left. Yolanda also reminded her audience at the community assembly of the material significance of their age: time is limited.

This last point certainly came to the fore on the occasions when speeches made at the weekly marches paused to note the passing of yet another jubilado, as it was in the concern expressed when a Wednesday regular missed a couple of weeks in a row. The fact of the jubilados advanced age was articulated most explicitly in two arguments made repeatedly. It was often noted that pensioners cannot be expected to wait indefinitely for real change if they are to get to see it in their lifetime. Sometimes, as for Yolanda, this argument was made in the face of competing claims for scarce resources. Alternatively, some of the more pessimistic noted that they were not fighting for their own gain - they did not expect to see the fruits of their political labour - but for future retirees.

Being activists also protected the jubilados from being subsumed into one of the only roles available to the elderly. As proud as they were of their grandchildren, the jubilados resisted being defined by their grandparenthood. In a conversation at the senior's center, Matilde let loose her outrage at the way Argentines refer to older people as "abuela" or "abuelo" (grandmother or grandfather). It is quite common for people to refer to unknown elders in this way, for example, someone on a bus might say, "would you like a seat, abuela?" I had always imagined this as a kind of affectionate respect, but Matilde certainly did not. "You don't know me! I am not your grandmother!" she declared.

For many, there was doubtless a social side to 
participating in the Jubilados' movement. Small gatherings of jubilados could be found in coffee shops (or, as with Ramón and José, fast food joints) near the Congress every Wednesday after the protests. Matilde, for one, emphasized how much she enjoyed the company of people her own age. Yet company was not reason enough; like many others, she expressed her disdain for seniors who went to centers only to play cards and gossip. She was one of those gathering signatures as described by Hector in the opening quote. Political debate, weekly protests, flu shot drives and collecting signatures were all more meaningful ways for her to spend her time.

\section{ConClusions}

The Jubilados are extraordinary. The mere fact that they have managed to sustain weekly protests for not just months or years but decades is in itself a remarkable feat. Add to this the advanced age of most members, and they truly defy expectations. The Jubilados struggle to practice a different kind of old age. They refuse to be defined as passive by their roles as retirees and grandparents, and they refuse to retire from political life. The jubilados' movement might be seen as a struggle for recognition in the broadest sense (Fraser 2000). Indeed, in the quotation at the beginning of this article Hector describes them as trying "to awaken the recognition of folks." They strive to express their points of view and to be heard. They want people to understand the plight of seniors in Argentina and to change how they think about and treat the elderly. As history workshop participants asserted: "we want to make our own contributions to the country."

It may be precisely because older people are apparently unlikely activists that the jubilados have much to teach us. Their example demonstrates how activism is more than just an effect of youthful discontent, as sometimes asserted, but comes from somewhere. With the benefit of hindsight, the jubilados are able to articulate some of the ways that they see their life experiences as having led them to their activism with the Mesa. ${ }^{19}$ Their example has the potential to act as an important corrective to some of the literature on social movements. This literature has made important advances to thinking about how and why groups win political spaces. Yet by focusing on group dynamics and resources, thinking about social movements risks overlooking historical continuities which can be traced through the life-stories of participants. Many formulations draw distinctions between 'old' and 'new' social movements, the former referring to traditional class politics (via parties and labour unions) and new ones, drawn around 'identities'. Yet the jubilados show how people move around among different kinds of political engagements throughout their lives. In a way that resonates with the jubilados' own views of their particular contributions to the fight for social justice in Argentina, we can see how the longer view helps us better understand where activists and their activism come from. They are clearly both the product of their collective and individual histories and makers of history.

\section{Acknowledgements}

I gratefully acknowledge the help, openness and insights of the Mesa Coordinadora de Jubilados y Pensionados de la República Argentina, the Centro de Jubilados AbastoOnce and the many jubilados who agreed to speak with me. Thanks to Mary Guadet for her various parts in this, as researcher, research assistant, and photographer. This research was conducted with the financial support of the Social Sciences and Humanities Research Council of Canada, Standard Research Grant. Finally, thanks to Sarah Lamb, Liesl Gambold, Jason Danely and two anonymous reviewers for their thoughtful and constructive comments on earlier drafts of this article.

\section{Notes}

1. There is work on voting, which is a qualitatively different form of political participation than that under examination here. See for example, Campbell (2003).

2. One distinctive characteristic of the gray panthers is their commitment to building intergenerational solidarity, including young people in their movement and employing the slogan "age and youth in action" (Sanjek 2009).

3. People were recruited at the weekly marches, where introductions often led to other interviews. Some people who did not participate in the marches were also recruited. Most of this group were participants at the Abasto-Once senior's center (described below). Some of this second group did also attend the marches. For reflection on some of the particular strengths and weaknesses of this methodology see DuBois (in press).

4. Throughout I use the actual names of jubilados by their choice, following common practice for oral history. Luciano asked that I use his "nom de guerre" (as he put it) instead.

5. Mary Gaudet was a Master's student who worked with me on the project. Her work focused on the senior's center Abasto Once, of which Hector Anzorena was president, and which was affiliated with the Mesa Coordinadora the main group organizing the pensions, see below (see Gaudet 2003).

6. For a discussion which compares life-course and generational approaches to politics see Braungart \& Braungart (1986).

7. The evaluation of Perón's motives and practices is still widely and passionately debated and cannot be addressed here. That said, there is little question that many state institutions were either made or dramatically remade in Perón's first two presidencies. His third presidency was short-lived, from 1973 to his death in 1974 (Rock 1987).

8. It should be noted that Pla was not a member of the Mesa, the group whose members I worked with. 
9. Although everyone refers to the obra social as PAMI, its official name is INSSJP for "Instituto Nacional de Servicios Sociales para Jubilados y Pensionados."

10. A rich feminist literature analyses how women get positioned as recipients of aid, see for example Gordon's edited collection featuring a number of the key authors (1990).

11. Linda Gordon evokes this notion in the title of her book about welfare in the U.S.: Pitied but not entitled (1994).

12. Of course, the jubilados also prize social and economic justice and in this sense would never object to the expansion of the social safety net.

13. Scholars have noted the peculiar and paradoxical nature of ageism: that it is a prejudice against one's future self (Jönson 2013). Jönson makes the interesting observation that this quite often is maintained through a temporal construction in which the non-old imagine old people as qualitatively different from themselves because they are from a different generation (2012).

14.Approximately 650,000 people 60 or older lived in the capital of Buenos Aires in 1998 (Encuesta Permanente de Hogares in Fassio and Golpe 1999:75).

15. Buenos Aires is a megacity including Gran Buenos Aires and the city of Buenos Aires. The latter, also known as la Ciudad Autonoma de Buenos Aires is a capital district, analogous to Washington D.C. The 2010 census places the population of the capital at 2.89 million. The total population of Gran Buenos Aires, including the capital, was 13.53 million (INDEC).

16. "Work-related" is defined as "connected to the work past of its members" through unions or professional associations (Fassio \& Golpe 1999:80).

17. Given that street protests are part of the Argentine repertoire, 40,000 is not a huge number, but a respectable one which would have helped get the jubilados' issues on the table.

18. The Madres are a group of mothers of the disappeared who publicly demanded the return of their missing children during the dictatorship, and when almost no one else dared criticize the military regime (Bouva rd 1994).

19. This is not accidental. People tell their life stories with a purpose, and these activists tended to narrate their lives in such a way as to explain their current priorities (see DuBois n.d.).

\section{REFERENCES}

Braungart, Richard B. and Margaret M. Braungart

1986 Life-course and Generational Politics. Annual Review of Sociology. 12:205-231.

Bossio, Diego and Amado Boudo

2010 Inclusion y prevision social en una Argentina responsable. Bueno Aires: Minesterio de Economia, Republica de Argentina; ANSES.

Bouvard, Marguerite G.

1994 Revolutionizing Motherhood: The Mothers of the Plaza de Mayo. London: Scholarly Resources Inc.

Campbell, Andrea Louise

2003 How Policies Make Citizens: Senior Political Activism and the American Welfare System. Princeton: Princeton University Press.

\section{Cufré, David}

2010 Con la moratoria se arrimó el bochín. Pagina/12,

Economia. Retrieved 6/24/2010.

Dantz, Giselle

2012 The Inextricable Link Between Sovereign Debt and Pensions in Argentina, 1993-2010. Latin American Politics and Society 54(1):101-126.

de la Sota, Hugo

2008 Carta De Lector: ¿A Quién Le Importan Los Jubilados? La Nación (9/3/2008).

DuBois, Lindsay

(In press) The Romance of Reminiscence: Problems Posed in Life Histories with Activist Pensioners in Argentina, In S. High, E. Little, and T. R. Duong (eds.) Remembering Mass Violence: Oral History, New Media and Performance. Toronto: University of Toronto Press.

Fassio, Adriana N. and Laura I. Golpe

1999 Población de edad y organizaciones de la sociedad civil. Revista De La Escuela De Economía y Negocios 1(3):73-92.

Fraser, Nancy

2000 Rethinking Recognition. Electronic document, http://www.newleftreview.org/?view=2248.

Fraser, Nancy, and Linda Gordon

1994 A Genealogy of Dependency: Tracing a Keyword of the U.S. Welfare State. Signs 19(2):pp. 309-336.

Gaudet, Mary

2003 "We are going to fight as long as we have life": Histories and Politics of Argentine Activist Pensioners. MA thesis, Dalhousie University.

Gordon, Linda

2012 Women, the State, and Welfare. Madison: University of Wisconsin Pres.

Gordon, Linda

1994 Pitied but Not Entitled: Single Mothers and the History of Welfare. New York: Free Press.

Jönson, Håkan

2013 We Will be Different! Ageism and the Temporal Construction of Old Age. The Gerentologist 53(2):198204.

Karush, Matthew B. and Oscar Chamoso, eds.

2010 The New Cultural History of Peronism: Power and Identity in Mid-Twentieth Century Argentina. Durham, NC: Duke University Press. 
Lloyd-Sherlock, Peter

1997 Old Age and Urban Poverty in the Developing World: The Shanty Towns of Buenos Aires. Houndmills, Basingstoke, Hampshire; New York, N.Y.: Macmillan Press; St. Martin's Press.

Minkler, Meredth and Martha B. Holstein

2008 From Civil Rights to... Civic Engagement? Concerns of Two Older Critical Gerontologists about a "New Social Movement" and What it Portends. Journal of Aging Studies 22:196-204.

Rock, David

1987 Argentina, 1516-1987: From Spanish Colonization to Alfonsín. Berkeley: University of California Press.

Rugel, Jean and Riggirozzi, Maria Pia

2007 The Return of the State in Argentina. International Affairs. 83(1):87-107.

Sanjek, Roger

2009 Gray Panthers. Philadelphia: University of Pennsylvania Press.

Sawchuk, Dana

2013 Peace Profile: The Raging Grannies. Peace Review. 25(1):129-135.

Tortti, Maria C.

2009 El "viejo" partido socialista y los origenes de la "nueva" izquierda (1955-1965). Buenos Aires: Prometeo libros.

Vilas, Carlos M.

2006 Neoliberal Meltdown and Social Protest:Argentina 2001-2002. Critical Sociology 34(1):163-186.

Zommer, Laura

1996 Falleció Norma Plá una mujer combativa. La Nación. 19 June. Retrieved 5/17/2010. 